\title{
Analysis on the Motivations, Experiences, and Lessons of Chinese Enterprises' Overseas Investment
}

\author{
Yingman Wang*, Wenxiu Qin, Ang Li \\ Wuhan Institute of Technology, Wuhan City, China \\ *Corresponding author: Yingman Wang, wym13797443752@163.com
}

\begin{abstract}
With the economic globalization, increasing numbers of Chinese entrepreneurs have taken an interest in international investments and acquisitions in order to expand their business territories around the world. Based on various motivations for international investments, this paper analyzed the challenges faced by Wanda, Fuyao Glass, and Fosun in regard to different business backgrounds and models, cultural concepts, as well as the changing global political and economic environments in addition to summarizing their experiences and lessons from international investments.
\end{abstract}

Keywords: International investment; Overseas investment; Motivation; Lessons learned; Direct investment

Publication date: June 2021; Online publication: June 30, 2021

\section{Introduction}

Since the reform and opening-up, China's economy has been rapidly developing and Chinese enterprises have been taking an increasing share of the global outward investment flow and stocks. In today's economic globalization, the overseas mergers and acquisitions (M\&A) have become one of the main approach for Chinese enterprises to expand their market internationally.

Successful overseas M\&A would usher in inestimable profits to enterprises. Although driven by complex motives, there are potential risks and numerous prerequisites that cannot be ignored. ${ }^{[1]}$

In the process of opening-up in 2013, China's local investors have made direct investments in 5,090 foreign enterprises which involved 156 countries and regions with a total of 90.17 billion US dollars of non-financial direct investment, up $16.8 \%$ year-over-year.

By the end of 2013, China's cumulative non-financial outward direct investment was US\$525.7 billion. In 2014, China's outward direct investment continued to grow rapidly, whereby it reached a record high value of US\$123.12 billion, up 14.2\% year-over-year.

Since 2003, China's outward investment has achieved 12 consecutive years of growth. In 2014, the flow was 45.6 times of that in 2002 with an average annual growth rate of $37.5 \%$.

In the same year, the gap between China's outward direct investment and inward investment was only 5.38 billion USD. For the first time, the two-way investment and trade have reached this kind of level.

In view of that, many outstanding Chinese companies have begun to expand their territories of overseas investment. 


\section{Motivation of Chinese Enterprises in Overseas Investment}

\subsection{Concept of motivation in foreign direct investment}

The motivation for foreign direct investment which is also known as the purpose for foreign direct investment reflects the factors that investors would consider when making investment decisions in view of necessity. This explains why investors would make certain types of investments. When investors decide on a foreign investment, they are influenced by the unique advantages of the enterprise yet restricted by the social and economic environment in which that enterprise is located.

Therefore, there are variations in the motives for overseas investment among different enterprises which leads to different investment projects of these enterprises.

\section{Motivation Analysis of Wanda, Fuyao Glass, and Fosun Group in regard to Overseas Investment}

\subsection{Wanda: Market-oriented motivation}

Wanda Group, which was established in 1988 is known as the largest cultural enterprise in China. The company has four major industries which are the commercial, cultural, internet, and financial industry. In the cultural industry, Wanda Film and Television Media Company accounts for the production and distribution of various films and TV series while expanding their business abroad. ${ }^{[2]}$ Wanda Group is committed to walk in the path of a high-end service industry. Their motive in overseas investment is marketoriented which is to consolidate, expand, and open-up the market.

As a successful entrepreneur of Wanda Group, Wang Jianlin has a keen and accurate judgment on the market. Although China's sports industry was still an infant-industry at that time, he started to develop a M\&A strategy in the global sports industry as early as 2015.

The State Council emphasized that the sports industry should be regarded as an important aspect in promoting social and economic development.

In 2016, Wanda Group became the top sponsor of FIFA which holds global marketing rights for FIFA and their events including the World Cup. Although the Chinese football industry was in an unprecedented situation, Wanda believed that as long as the economy keeps improving, the football industry in China and Asia itself would have a bright future; hence, it was "extremely worthwhile" to sponsor football.

On January 12, 2016, Wanda Group took another step forward in the global footprint with the acquisition of Legendary Pictures. It was obvious that the M\&A value was not on their films. The first reason was because Legendary Pictures owned thousands of intellectual property rights and with that in mind, Wanda Pictures would be able to develop numerous derivative products to support Wanda's tourism and children's entertainment industries to achieve synergies. Second, the acquisition would strengthen Wanda's voice in the global film industry and lastly, it would increase the comparative benefits and achieve a win-win situation for both sides.

\subsection{Fuyao: Technology and management-oriented, preferential policy-oriented, cost-reduction- oriented motivation}

With the economic globalization and the continuous advancement of the "Go Out" policy in China, increasing numbers of manufacturing enterprises ventured into foreign markets for productions, operations, investments, and financing activities to improve internationalization. However, the frequent fluctuations of exchange rates antagonized the multinational corporations' judgments in regard to the uncertainties of future operating results and cash flow which might cause substantial risks to enterprises. ${ }^{[3]}$ Fuyao Group is a supplier of automotive glass production with the largest scale, highest technology level, and largest export volume. "FY" trademark is so far the only "China well-known trademark" in China's automotive glass industry. 
In general, the motivations of Fuyao Glass for overseas investment are technology and managementoriented, preferential policy-oriented, as well as cost-reduction-oriented.

In the early stages, Fuyao Glass bought foreign equipment that was considered unsatisfactory at that time, sent company teams overseas to train, mastered core technologies, and learned to make glass production equipment.

A series of subsidies were also rendered for manufacturing in which lands and electricity were cheaper as the U.S. governement encouraged glass manufacturing in addition to the recovery of manufacturing power status.

Only human resources were relatively expensive. The Fuyao factory in United States not only saved on production costs but also on tariffs. The investment in United States was an excellent choice. In the early stages, Fuyao used the distribution model to sell glass and a large amount of profits flowed in for foreign distributors. Hence, in the first three years, the company suffered a great loss. Fuyao approached the American consultants and discovered the problem. Subsequently, Fuyao Glass changed their distribution to direct sales and immediately, made up for the losses in the previous three years.

\subsection{Fosun: Market-oriented motivation}

For a long time, Fosun Company has been regarded as a "multi-industry company" or "more than specialized." However, after Fosun made it clear that they aimed to be a "world-class investment group," the talk seemed to stop. With investment models, Fosun rearranged the company's situation and everything else followed.

Fosun successfully combined diversity and professionalism. Up to now, Fosun's profits are derived from three sources which are the industrial profits, investment profits, and asset management incomes. Alike Wanda, their overseas investment motive is also market-oriented. They have selected foreign companies such as Cirque du Soleil, in which they believe that foreign companies require China's vast market, partners, and Chinese cultural elements.

\section{Analysis on the Overseas Investment Experiences and Lessons of Wanda, Fuyao Glass, and Fosun}

\subsection{Wanda: Success by analyzing future trends}

Wanda has invested in Wanda Plaza at Changbai Mountain whereby in the name of high-end goods and costly transportations, it is more expensive to sell in the mall compared to the outside. Tourists usually visit Changbai Mountain to view the scenery and not for consumption. Although there was a business boom for a short period, it became bleak in the long run. Merchants who stayed in Changbai Mountain could not afford the expensive rental so they had to leave the site one after another.

Therefore, a lesson was drawn from this in which immediate interests of investments should not only be considered but the trends and directions of future development should be closely analyzed in regard to the society. In simpler terms, by being attentive to the development of society, it is then possible to move forward into the future.

\subsection{Fuyao: Mastering core technology and implementing localization strategy}

Fuyao glass first arrived in the United States with the distribution model and during the first three years, it was in deficit. The distribution model was straigthened out to reverse the situation.

Fuyao Glass has become a global automotive glass manufacturing giant with their grasp in core technology. Improving autonomous technology at the kernel is essential for the development of the company. 
In regard to the overseas M\&A, some small businesses do not have the cautiousness and core competitiveness to enter the overseas markets; hence, it is likely for them to lose everything. Fuyao Glass believes that manufacturing is an indispensable aspect for the survival of a country. Hence, in foreign investments and factory constructions, the localization princple is used by Fuyao Glass in which workers from both countries are equally treated and local people are regarded as the "parents." This principle has won the support of the local people and smoothened the industrial process.

\subsection{Fosun: China's power to graft global resources in creation of an ecological chain with synergistic effect}

With the boom of M\&A all around the world, Chinese enterprises have also embraced the flow to seek a wider path for development. The strategic M\&A have many aspects which is far more superior than the financial ones. For strategic M\&A, the realization of synergistic effect is the power source. In this field, Fosun International has been playing an important role as the strategic driving force. They have large numbers of M\&A, funds, and they are known as one of the most rapidly developing enterprises in the comprehensive industry being a typical illustration of the strategic M\&A. ${ }^{[4]}$ Guo Guangchang believes that good things should be shared with the world. Hence, Fosun Group have been integrating and grafting global resources. In the future, invested enterprises would be consorted into an ecological chain forming a synergistic group of enterprise rather than independent ones. In this way, Fosun Group would serve as a model for other smaller Chinese companies to emulate in creating a virtuous circle of international investments.

\section{Conclusion}

With the economic globalization, enterprises are no longer satisfied with domestic development; hence, the cross-border mergers and acquisitions of Chinese enterprises are gradually increasing. M\&A are important for Chinese enterprises to strengthen their competitiveness while expanding their territories. Overseas mergers and acquisitions play an important role in market developments and optimizing resource allocations for enterprises. ${ }^{[5]}$

\section{Disclosure statement}

The author declares no conflict of interest.

\section{References}

[1] Li M, 2021, Influencing factors of Chinese enterprises' overseas mergers and acquisitions. Journal of Shansi University of Finance and Economics, 43(S1): 21-27.

[2] Li L, 2020, Risk analysis of private enterprises expanding International market - based on the case of Wanda Group's acquisition of Legendary Pictures. Western China Finance \& Accounting, (04): 60-63.

[3] Liu X, 2020, Research on foreign exchange risk management strategy of China's multinational manufacturing enterprises. Guangdong University of Foreign Studies.

[4] Tang Z, 2020, Research on synergistic effect of Fosun International strategic mergers and acquisitions. Lanzhou University.

[5] Li Q, 2019, Analysis of the status quo of Chinese enterprises' overseas mergers and acquisitions. Market Research, (09): 44-45. 